\title{
Pergumulan Dakwah di Mentaya Sampit
}

\author{
Yusuf Alkhusaeri ${ }^{*}$, Nanih Machendrawaty ${ }^{1}$, Acep Aripudin ${ }^{2}$ \\ 1Jurusan Komunikasi dan Penyiaran Islam. UIN Sunan Gunung Djati Bandung \\ 2Prodi Komunikasi dan Penyiaran Islam, Pascasarjana UIN Sunan Gunung Djati Bandung \\ *Email: yusufalkhusaeri08@gmail.com
}

\begin{abstract}
ABSTRAK
Tujuan dalam penelitian ini antara lain : Pertama, memahami aspek - aspek dakwah dalam pelaksanaan Ritual Mandi Safar. Kedua mengetahui dan menganalisis suatu elemen - elemen yang memicu pro dan kontra di dalam pelaksanaan Ritual Mandi Safar. Metode penelitian yang digunakan adalah metode kualitatif, sumber data pada penelitian ini adalah sumber data primer, yaitu pelaku dan pihak - pihak yang mengetahui sejarah Ritual Mandi Safar. Adapun teknik pengumpulan data yang digunakan dalam penyusunan peneliti ini adalah teknik observasi, wawancara, serta dokumentasi. Berdasarkan hasil penelitian dapat disimpulkan bawa Mandi Safar merupakan Ritual yang bernuansa agama, namun pada dasarnya tradisi tersebut bukanlah bagian dari agama. Dalam Ritual Mandi Safar yang perlu dikedepankan adalah sapek "tradisi dan budaya" bukan aspek Ritual keagamaannya, karena akan timbul pemahaman syirik pada masyarakat. Aspek - aspek dakwah yang terkandung di dalam mandi safar yaitu, aspek sosial yaitu, kebersamaan dan kesetiakawanan dan aspek aqidab yaitu, kepercayaan dan keyakinan yang dapat menyelaraskan dengan timbulnya prilaku yang mementingkan kepentingan bersama atau nilai solidaritas dalam tindakan masyarakat.
\end{abstract}

Kata kunci: Pergumulan Dakwah, Pro dan Kontra, Konflik Sosial

\begin{abstract}
The objectives in this study include: First, understand of da'wah in the implementation of the Ritual of Mandi Safar. The two know and analyze an element that triggers pro and contra in the implementation of the Ritual of Mandi Safar. The research method used is a qualitative method, Data sources in this study are primary data sources, namely the perpetrators and partys who know the history of the Ritual of Mandi Safar. The data collection techniques used in the preparation of this researcher are observation, interview, and documentation techniques. Based on the results of the study it can be concluded that Safar Bath is a Ritual that has a
\end{abstract}


Y. alkhusaeri, N. Machendrawaty, A. Aripudin

religious nuance, but basically the tradition is not part of religion. In the Ritual of Mandi Safar, which needs to be put forward, the sapek "tradition and culture" is not an aspect of its religious Ritual, because will arises comprehension syirik on society. Aspects of da'wah contained in safar baths are, social aspects namely, togetherness and solidarity and aspects of aqedah namely, trust and confidence that can harmonize with the emergence of behavior that conserned interest shared or the value of solidarity in community actions.

Keywords: Struggle Da'wah, Pro and Contra, Sosial Conflict

\section{PENDAHULUAN}

Upacara Tradisi Mandi Safar adalah suatu upaya spritual pendekatan diri kepada Allah yang dilakukan oleh sebagian masyarakat muslim di beberapa wilayah di Indonesia, diantaranya di wilayah di Nusa Tenggara Barat, Sulawesi, Kepulauan Riau, Maluku, termasuk di salah satu wilayah sungai Mentaya Kota Sampit Kabupaten Kotawaringi Timur Kalimantan Tengah.

Terkait dengan eksistensinya tradisi Mandi Safar ini tentu menimbulkan pro dan kontra di kalangan masyarakat itu sendiri. Di satu sisi ada yang beranggapan sebagai tindakan bid'ah yang tidak boleh dilakukan karena bertentangan dengan ajaran Islam yang melarang adanya takhayul dan khurafat serta mengandung unsur syirik, sedangkan di satu sisi lainnya ada yang berpendapat bahwa ritual Mandi Safar hanyalah sekedar tradisi leluhur bernafasakan Islam yang perlu dipelihara kelestariannya, tentunya dengan mengedepankan modifikasi - modifikasi Islami dan menghilangkan unsur unsur mistisisme. (Moesliem, 2003: 155).

Konflik yang muncul akibat perbedaan budaya salah satunya disebabkan oleh sikap fanatisme sempit dan kurangnya sikap tasamub (toleran) dikalangan umat. Fanatisme dan toleransi hanya akan menyebabkan terjadinya desintegrasi bangsa dan konflik di masyarakat. Jika tradisi dan budaya diasumsikan dalam masyarakat ibarat pedang bermata dua. Di satu sisi ia merupakan kekayaan masyarakat Indonesia di lain sisi dapat menjadi faktor konflik horizontal. Persoalan paling utama bagaimana cara menjembatani tradisi dan budaya tersebut. Mampukah Islam sebagai agama yang diklaim "rahmatan lil alamin dan sholihun li kulli zaman wa makan" menjadi mediator bagi perbedaan perbedaan budaya. (Jandra, 2002: 1-3).

Bila melihat dari eksistensi ritual - ritual yang ada di beberapa wilayah Indonesia, masyarakat cenderung menerima pola akomodatif-reformatif atau pribumisasi Islam ketimbang pola purifikasi Islam. Hal ini cukup beralasan karena setiap orang lahir dari lingkungan "adat" dan kulturalnya masing masing. Oleh karena itu, Moeslim Abdurrahman mengatakan,

"Sulit diterima jika ada kenyataan Bahwa seseorang bisa beragama secara "murni", tanpa dibentuk oleb kulturnya. Kecuali mungkin seorang nabi atau rasul sunggub yang boleb mengatakan bahwa ia telab mendapatkan wabyu dari Tuban. Namun selebibnya, jika orang 
biasa saja, pengetabuan dan cara bagaimana mengungkapkan keberagamaan, tidak lain hal itu diperoleb karena diajarkan oleh orang tuanya, oleh guru dam kyai - kyai, babkan oleh kebiasaan - kebiasaan yang diwarisi begitu saja dari tradisi sekitarnya". (Moesliem, 2003: 19).

Mengajak dan mengajarkan memperbaiki lingkungan tentu sesuai dengan konsep dakwah yaitu mengajak kepada kebaikan dan mencegah dari kemungkaran, sebagaimana firman Allas Swt. dalam QS. Ali Imron: 104 yang artinya: "Dan hendaklah ada di antara kamu segolongan umat yang menyeru kepada kebajikan, menyuruh kepada yang ma' ruf dan mencegah dari yang munkar; merekalah orang-orang yang beruntung" (Depag RI, 2015: 63). Masyarakat diajak untuk kembali melestarikan lingkungan sekitar mereka dan diajarkan untuk tidak hanya mengambil manfaat dari lingkunganya sehingga terjadi kerusakan. Merubah pola fikir dan gaya hidup mad'u tentulah memerlukan metode yang baik dan tepat, apalagi memberi pamahaman kepada masyarakat yang menggantungkan hidupnya kepada hasil bumi dari hutan.

Sebagaimana yang dilakukan Tuan Guru Haji Hasanain Juaini, MH. yang telah berhasil menggerakkan santri dan masyarakat di Nusa Tenggara Barat untuk melestarikan lingkungan dengan cara menanam pohon. Beliau berhasil menghijaukan kembali 56 hektar lahan gundul yang ada di Lombok. Mengutip wawancara Hananto dari Mongabay (2014) pada tahun 2003 silam beliau membeli lahan gundul dan gersang seluas 36 hektar, dan sekarang telah menjadi kawasan konservasi hutan yang diberi nama Desa Madani. Pada tahun 2016 beliau menerima penghargaan Kalpataru katagori Pembina Lingkungan dari Kementrian Lingkungan Hidup dan Kehutanan yang diberikan langsung oleh Wakil Presiden RI Bapak Dr. (HC) H. Muhammad Jusuf Kalla di Istana Siak Sri Inderapura Kabupaten Siak, Riau.

Yang membedakan penelitian ini dengan penelitian penulis adalah tentang fokus masalah, sedangkan persamaannya adalah sama sama mengkaji tentang tradisi pada msayarakat.

Penelitian ini dilakukan di Sungai Mentaya Kota Sampit Kabupaten Kotawaringin Timur Kalimantan Tengah. Objek penelitian dengan wawancara kepada pribumi, sejarawan, atau bahkan tokoh adat dan tokoh masyarakat.

Berpijak pada latar belakang diatas maka muncul pertanyaan, yaitu : pertama, bagaimana proses dakwah melalui tradisi mandi safar, sehingga menimbulkan pro dan kontra?. Kedua, bagaimana pendapat masyarakat kelurahan pasir putih tentang tradisi mandi safar?

Metode Penelitian yang peneliti gunakan yaitu dengan metode kualitatif tentang Tradisi Mandi Safar. Jenis penelitian yang dipakai oleh peneliti adalah jenis kualitatif yang mempelajari masalah - masalah yang ada serta tata cara kerja yang berlaku. Penelitian kualitatif ini bertujuan untuk mendeskripsikan apa - apa 
Y. alkhusaeri, N. Machendrawaty, A. Aripudin

yang saat ini berlaku. Di dalamanya terdapat upaya mendeskripsikan, mencatat, analisis dan menginter pretasiakan kondisi yang sekarang itu terjadi atau ada. Dengan kata lain penelitian kualitatif ini bertujuan untuk memperoleh informasi - informasi mengenai keadaan yang ada. (Mardalis, 1999: 26).

\section{LANDASAN TEORITIS}

Sebelum Islam masuk ke Indonesia, masyarakat Indonesia sudah memeluk kepercayaan agama Hindu, Budha, dan kepercayaan primitif (animisme dan dinamisme). Setelah datangnya Islam, kepercayaan lama yang mereka yakini masih saja ada dalam pikiran dan tetap dilaksanakan dalam kehidupan sehari hari. (Kusumah, 1993: 103).

Menurut Abdurahman Wahid, Arabisasi atau proses mengindentifikasi diri dengan budaya Timur Tengah akan tercerabutnya kita dari akar budaya kita sendiri. Arabisasi belum tentu cocok dengan kebutuhan kita. Menurutnya antara agama Islam dan budaya memiliki independensi masing - masing, tetapi keduanya memiliki wilayah yang tumpang tindih. Tumpang tindih agama dan budaya akan terus terjadi sebagai suatu proses yang akan memperkaya kehidupan dan membuatnya tidak gersang. Dari sisilah sebenarnya gagasan tentang pribumisasi Islam menjadi sangat urgen. Karena dalam pribumisasi Islam tergambar bagaimana Islam diakomodasikan ke dalam budaya yang berasal dari manusia tanpa harus kehilangan identitsnya. (Wahid, 2001: 19-20).

\section{Kajian Teoritis}

Menurut Max Weber konflik mempuyai posisi sentral dalam menganalisis kehidupan masyarakat. Konflik merupakan unsur dasar kehidupan manusia. Pertentangan tidak dapat dilenyapkan dari kehidupan budaya. Dia juga menyatakan bahwa masalah kehidupan modern dapat dirujuk ke sumber materialnya yang rill misalnya, struktur kapitalisme. Oleh karena itu penyelesaian hanya dapat ditemukan dengan menjungkirbalikan struktur kapitalis itu melalui tindakan kolektif sejumlah besar orang. Orang yang memang dapat mengbah sarananya, akan tetapi orang tidak dapat membuang konflik itu sendiri. (Wirawan, 2012: 66-70).Ada beberapa pokok pemikiran menurut Weber, yaitu:

Pertama, Tindakan Individu dalam arti Subjektif, bahwa hanya individual yang ril secara objektif, sedangkan masyarakat hanyalah satu nama yang menunjuk pada sekumpulan individu. Pemahaman subjektif (verstehen) adalah sebagai metode untuk memperoleh pemahaman yang valid mengenai arti subjektif tindakan sosial.

Kedua, Tipe Ideal menurut Weber adalah suatu teknik metodologi dengan cara penekanan yang berat sebelah (berpihak) mengenai suatu pokok pandangan atau lebih, sintesa gejala - gejala individual kongkrit, tersebar, sifatnya sendiri - 
sendiri yang ada ataupun tidak ada. Kurang lebih diatur menurut titik pandang yang diberi tekanan secara berat sebelah kedalam suatu kontruksi analitis tertentu.

Ketiga, Tipe tindakan Sosial. Tipe tindakan sosial dasarnya adalah rasionalitas.

Keempat, Stratifikasi Sosial dasarnya adalah ekonomi, budaya dan politik. Ukuran ekonomi dasarnya bersumber dalam kesempatan hidup, pemilik benda untuk memproleh kesempatan, kondisi komoditas dalam pasar tenaga kerja.

Kelima, Tipe otoritas meliputi : Otoritas Tradisional, Otoritas Kharismatik, dan Otoritas Legal Rasional.

Keenam, Orientasi Agama yaitu ide agama mempunyai pengaruh independen terhadap prilaku manusia. Ide agama berpengaruh dalam meningkatkan perubahan sosial. (Soelaeman, 2011: 44-46).

Menurut Talcott Persons teori fungsional dapat dilihat dari agama sebagai penyebab sosial yang dominan dalam terbentunya lapisan sosial, perasaan agama, dan termasuk konflik agama. Agama dipandang sebagai lembaga sosial yang menjawab kebutuhan mendasar yang dapat dipenuhi kebutuhan nilai - nilai duniawi. Tetapi tidak mengutik apa yang ada di luar atau referensi trasendental. (Soelaeman, 2011: 280).

Ajaran Islam yang dikemukakan oleh $\mathrm{Al}$ - Ghazali (abad ke 11) tentang konflik dalam fitrah manusia, mengemukakan bahwa manusia mempunyai tiga tahap perkembangan jiwa yaitu:

Pertama, Nafs - al - amarab bil alsu, yaitu nafsu yang mendesak agen moral untuk melampiaskan tuntunan - tuntunan yang tidak terkontrol atau nafsu yang mengendalikan kejahatan. Individu tunduk kepada tujuan - tujuan yang didasari oleh sikap emosi, hatinya diperbudak oleh tujuan tersebut. Alquran menyatakan: "......nafsu itu selalu menyurub kepada kejahatan....." (QS. Yusuf : 53)

Kedua, Nafs - al - lawwamah atau nafsu yang disalahkan, yaitu nafsu yang sadar apabila tuntutan - tuntutan naluriah yang dilampiaskan atas pengaruh nafs - al - amarab. Nafs ini berusaha melawan nafs - al-amarah. Perkembangan jiwa sehat terletak pada aksi timbal balik, dimana nafs - al - lawwamah mengalahkan nafs - al - amarah. Sekali nafsu jahat ini di kalahkan, maka manusia memasuki tahap jiwa di atas nafs yang sadar yaitu nafs yang ketiga.

Ketiga, Nafs - al - muthmainnah (nafsu yang tenang dan tentram), merupakan keadaan kepuasan tertinggi dari nafs. Keadaan nafs atau jiwa ini, betul - betul memperoleh kepuasan yang lengkap dan bebas dari semua keputusan dan penderitaan. (Soelaeman, 2011: 49).

Media komunikasi tradisional, merupakan media yang digunakan oleh masyarakat tertentu yang berbeda dari masyarakat lainnya disebabkan ciri-ciri khas sistem masyarakat tersebut beserta tata nilai kebudayaannya. Media 
Y. alkhusaeri, N. Machendrawaty, A. Aripudin

komunikasi tradisional terutama seni pertunjukkan sampai saat ini masih dianggap penting, sebagai alat untuk menyampaikan pesan-pesan pembangunan, terutama pembangunan mental spiritual. Hal ini sejalan dengan pendapat Harmoko (1986:86) sebagai berikut :

Media tradisional adalah berbagai macam seni pertunjukkan yang secara tradisional dipentaskan di depan khalayak terutama sebagai sarana hiburan yang memiliki sifat komunikatif, sehingga bentuk kesenian itu dapat dimanfaatkan sebagai media pembawa pesanpesan penerangan. Unsur tradisional dan sifat komunikatif dari seni pertunjukkan tersebut, memudahkan untuk dijadikan sebagai media penerangan yang efektif, tanpa harus kehilangan unsur hiburannya. Efektifitas tersebut sebagian tersebar disebabkan oleh karena seni pertunjukan memang bersifat merakyat, dan dengan demikian mudah untuk dapat langsung menggugah hati khalayak. Itulah sebabnya bentuk kesenian ini sering disebut sebagai pertunjukkan rakyat. (Nurhidayah, 2017: 22).

\section{Kajian Konseptual}

Pergumulan Islam dan budaya Jawa melalui pendekatan Islamisasi Jawa dan Jawanisasi Islam masih menyisakan sebuah persoalan. Melalui proses yang damai tanpa ketegangan dan konflik. (Paisun, 2010: 1). Dalam rentang periode sejarah yang panjang dari generasi ke generasi, Islam sebagai pembawa nilai - nilai budaya baru, belum mampu menggantikan seluruhnya nilai - nilai budaya lama dibawah religi animisme dan dinamisme maupun agama Hindu dan Budha. Artinya orang Islam pada satu sisi taat menjalankan doktrin - doktrin agama Islam dan pada satu sisi lainnya taat menjalankan budaya, tradisi, ritual, dan keyakinan leluruh yang ada kalanya mengandung unsur syirik dan bertentangan dalam ketentuan syariat Islam.

Lebih khusus tradisi yang dapat melahirkan kebudayaan masyarakat dapat diketahui dari wujud tradisi itu sendiri. Menurut Koentjaraningrat, kebudayaan itu mempunyai paling sedikit tiga wujud, yaitu:

Pertama, Wujud Kebudayaan sebagai suatu kompleks ide-ide, gagasan gagasan, nilai-nilai, norma-norma, peraturan, dan sebagainya.

Kedua, Wujud kebudayaan sebagai kompleks aktivitas kelakuan berpoladari manusia dalam masyarakat.

Ketiga, Wujud kebudayaan sebagai benda-benda hasil karya manusia. (Mattulada, 1997: 1).

Dalam proses lalu lintas manusia antarbudaya, dakwah merupakan nilai. Nilai dakwah yang dimaksud adalah Islam. Islam, baik memaknai sebagai sikap maupun dipahami sebagai sistem nilai dan pesan yang meyertai suatu dakwah, 
seperti dalam tabligh, menjadi sangat penting ketika bersentuhan dengan nilai nilai budaya yang dianut masyarakat. Karena tidak sepenuhnya budaya - budaya yang berkembang dalam masyarakat itu baik dan maslahat bagi manusia meskipun budaya tersebut sudah ada dan berkembang dalam masyarakat. (Aripudin, Sambas, 2007: 3).

Terlebih kalau berpegang pada pendapat Mac Iver yang menyatakan bahwa kebudayaan adalah ekspresi jiwa yang terwujud dalam cara-cara hidup dan berpikir, pergaulan hidup, seni kesusastraan, agama, rekreasi dan hiburan. Atau didasarkan pada pendapat Kingsley Davis, yang menyatakan bahwa kebudayaan mencakup segenap cara berpikir dan bertingkah laku, yang timbul karena interaksi yang bersifat komunikatif (dalam Soekanto, 2015: 341-343), maka kebudayaan secara fungsional berfungsi untuk dijadikan acuan dalam cara berpikir, gaya hidup, dalam pergaulan atau pola berhubungan hubungan satu sama lain. Kemudian Soerjono Soekanto memperjelas, bahwa:

Kebudayaan mengatur agar manusia dapat mengerti bagimana seharusnya bertindak, berbuat, menentukan sikapnya kalau mereka berhubungan dengan orang lain. Karena kebudayaan mewujudkan norma dan nilai sosial kemasyarakatan. Kebudayaan, akan mewujudkan kaidah-kaidah yang dinamakan peraturan yang bertujuan membawa suatu keserasian dan memperhatikan hal-hal yang bersangkut paut dengan keadaan lahiriah dan bathiniah manusia, yang salah satunya mengatur pola perilaku (patterns of behavior), dimana pola-pola perilaku tersebut Dakwah Kultural dalam Upacara Adat Ngalaksa Ilmu Dakwab: Academic Journal for Homiletic Studies, Vol. 10 No.2 | Juli-Des 2016101 merupakan cara-cara masyarakat bertindak atau berkelakuan yang sama dan harus diikuti oleh semua anggota masyarakat. Pola perilaku tersebut dilakukan dan dilaksanakan pada khususnya apabila seseorang berhubungan dengan orang lain yang dinamakan social organization (2015:195). (Aliyudin, 2016: 100 - 101).

Berdasarkan penjelasan di atas, dapat dipahami bahwa agama dan budaya merupakan bagian inheren dari kehidupan masyarakat, karena ia memiliki fungsi mendasar dalam kehidupan masyarakat, maka agama dan sosial-budaya juga mempengaruhi seluruh aspek kehidupan masyarakat. Dalam hal ini, Weber beranggapan bahwa jika orang memeluk agamanya secara serius, maka paling tidak tingkah-lakunya akan dipengaruhi oleh agamanya (Cuzzort dan King, 1987: 11).

Islam sebagai agama, seharusnya tidak dipahami sebagai seperangkat doktrin dan sistem moral yang terpisah dari kehidupan manusia. Ia tidak mengandung nilai - nilai dalam dirinya, tetapi mengandung ajaran yang menanamkan nilai - nilai sosial kepada penganutnya. Sehingga ajaran agama 
Y. alkhusaeri, N. Machendrawaty, A. Aripudin

merupakan elemen yang membentuk sistem nilai budaya. (Dhofier, wahid, 1978: 27).

Agama, manusia, dan budaya berhubungan secara dialektik. Hubungan agama, manusia, dan budaya di satu sisi menciptakan sejumlah nilai bagi masyarakatnya, dan pada sisi lain secara bersamaan, manusia secara kodrati senantiasa berhadapan dan berada dalam masyarakatnya (homosocius) (Kahmad, 2011 : 72). Agama dalam konteks budaya, berada dalam dialektika ini. Oleh karena itu, semua masyarakat yang dikenal di dunia ini, sampai batas tertentu, bersifat religious (Schraf, 1995: 29). Sementara perbedaan agama sebagai produk budaya dengan produk lainnya. Agama berasal dari proses objektivikasi tertentu yang bernilai transenden. Sebagai proses objektivikasi, maka di dalamnya akan melibatkan hubungan antara kebudayaan dan artefak. Hal yang sama terjadi ketika ada suatu agama masuk pada masyarakat lain di luar masyarakat pembentuknya. Agama itu akan mengalami proses penyesuaian dengan kebudayaan yang telah ada. Ada kompromi nilai atau simbol antar agama yang masuk dengan kebudayaan lokal, yang menghasilkan bentuk baru yang berbeda dengan agama atau budaya asal (Schraf, 1995: 75). Sementara dakwak dan budaya tidak dapat disangkal lagi keterkaitannya. Keduanya saling mengisi dan membantu dalam membutuhkan dalam menjalankan tugas dan fungsinya. Seperti yang dikatakan Asep Saeful Muhtadi Setiap peristiwa dakwah senantiasa berada dalam konteks budaya yang mengitarinya. Bagaimana subjek dakwah melakukan kegiatan dakwahnya, dan bagaimana mad'u berperilaku di tengah dakwah, tentu saja selalu membawa dan melibatkan latar budayanya (dalam Tajiri, 2015: 93)

Media adalah sebuah bentuk perantara yang digunakan oleh manusia untuk menyampaikan atau menyebarkan ide, gagasan atau pendapat, sehingga ide, gagasan atau pendapat yang disampaikan itu dapat diterima oleh orang yang dituju (Arsyad, 2002:4).

Sastropoetro (1987:16) menjelaskan bahwa media komunikasi itu dibagi dua golongan yakni media modern dan media tradisional. Adapun yang dimaksud media komunikasi tradisional adalah media yang dipergunakan secara turun temurun oleh nenek moyang manusia diantaranya api, asap, bunyibunyian, kentong, tambur, genderang, bedug dan sejenisnya. Sedangkan Effendy (1981: 370) mendefinisikan media tradisional secara khusus adalah media yang dipergunakan oleh khalayak pada masyarakat tertentu secara turun temurun. Penyisipan pesan pada model media komunikasi tradisional sebenarnya hanya sekilas saja, sebab yang paling dominan yang dipertunjukkan adalah lakon dan humornya (hiburannya). Namun, menurut Hidayat (2007:10), "nampaknya, komunikasi massa tradisional paling memungkinkan pelaksanaannya untuk daerah pedesaan. Apabila suatu daerah memiliki perkumpulanperkumpulan wayang golek, reog, longser, dongbret dan lainya, hal ini perlu mendapat 
pembinaan dari instansi-instansi terkait. Melalui perkumpulan-perkumpulan kesenian seperti itulah pesan-pesan tertentu dapat disebarluaskan". (Nurhidayah, 2017: 27).

\section{HASIL DAN PEMBAHASAN}

Kota Sampit terletak di tepi Sungai Mentaya. Dalam Bahasa Dayak Ot Danum, Sungai Mentaya itu disebut batang danum kupang bulan. Sungai Mentaya ini merupakan sungai utama dan dimanfaatkan sebagai prasarana perhubungan di Sampit. Sungai Mentaya merupakan sungai kebanggan masyarakat Sampit karena luas dan panjangnya sungai mentaya, sehingga Sampit bisa di sebut dengan sebutan Kota Mentaya

Sampit merupakan salah satu kota terpenting di Provinsi Kalimantan Tengah, karena secara ekonomis merupakan daerah kabupaten yang relatif maju dan juga terletak di posisi yang strategis. Dilihat dari peta regional Kalimantan Tengah, kota Sampit sebelumnya terletak di tengah - tengah dan ini menyebabkan posisinya sangat strategis. Misalnya, warga dari Buntok mau ke Pulau Jawa, maka akan lebih dekat jika melewati Kota Sampit daripada harus ke Kota Banjarmasin. Begitu pun kalau dari Palangkaraya, Kuala Pembuang, maupun Kasongan. Jadi, posisi strategis tersebut akan meningkatkan keunggulan komparatif pelabuhan laut Sampit yang dimiliki daerah ini, terutama akan menarik perekonomian dari kabupaten yang ada di sekitar wilayah Kotawaringin Timur. (Sumber Data: Dinas Kebudayaan dan Pariwisata Kotawaringin Timur).

\section{Proses Tradisi Mandi Safar yang Menimbulakan Pro dan Kontra.}

Setiap tradisi yang dilakukan oleh suatu masyarakat biasanya memiliki makna dan manfaat yang dirasakan oleh masyarakat. Tradisi tersebut juga mendorong masyarakat semakin melakukan dan mentaati tatanan sosial. Tradisi - tradisi ini memberikan motivasi dan nilai - nilai pada tingkat yang paling dalam. (Amin, 2002: 122).

Salah satu tradisi yang hingga kini masih sering dilaksanakan oleh masyarakat Islam diberbagai wilayah Indonesia salah satunya Tradisi Mandi Safar. Kegiatan Mandi Safar ini bertujuan mengangkat budaya lokal. Dengan begitu, seluruh masyarakat Indonesia lebih mengetahui budaya yang ada di Kotim. Kegiatan budaya Mandi Safar merupakan tradisi masyarakat yang mendiami tepian Sungai Mentaya, dipromosikan sebagai atraksi wisata Provinsi Kalteng.

Tradisi Mandi Safar adalah tradisi turun menurun yang tinggal di daerah pesisir sepanjang sungai Mentaya, dinamakan Mandi Safar karena tradisi ini dilaksanakan pada hari Arba Musta'mir atau hari Rabu terakhir bulan Safar setiap tahun Hijriyah. 
Y. alkhusaeri, N. Machendrawaty, A. Aripudin

Kenyakinan masyarakat bahwa pada bulan Safar adalah kesempatan untuk mensucikan seluruh tubuh, karena jika badan dan jiwa yang kotor akan mudah datangnya bencana yang menimpa. Dengan begitu kepercayaan ini masih dominan dilakukan pada setiap tahunnya. Kejadian ini juga yang menimpa para Rasul dan Nabi antara lain:

Pertama, Diselamatkanya kapal Nabi Nuh dari bahaya banjir.

Kedua, Terhindarnya Nabi Ibrahim dari bahaya api.

Ketiga, Terhindarnya Nabi Musa dan Nabi Harun dari bahaya ditelan laut

Kegiatan tradisi Mandi Safar ini merupakan salah satu atraksi budaya yang bernuasa agama yang akan selalu dipromosikan guna menambah perbendaharaan objek wisata Kalimantan Tengah. Dengan banyaknya atraksi budaya diharapkan Kalimantan Tengah lebih dikenal luas terutama Sampit Kabupaten Kotawaringin Timur sehingga banyak wiasata mengunjungin wilayah ini. (Rois, wawancara: 29 September 2018).

Untuk mengawali Mandi Safar masyarakat setempat mengawalinya dengan sholat zuhur berjamaah bagi umat Muslim dan doa bersama untuk tolak bala. Masyarakat yang ingin mengikuti tradisi Mandi Safar sebelumnya sudah dibekali diri dengan daun Sawang (sejenis daun sakral yang di anggap masyarakat sekitar sebagai daun suci), adapun filosofi dari Daun Sawang ini adalah melambangkan kesuburan serta kematian dan selalu mengingatkan kita pada sang pencipta alam, karena Daun Sawang tersebut banyak tumbuh subur dikuburan. Daun Sawang ini diikat dikepala atau dipinggang. Sebelum digunakan daun Sawang ini dirajah (merupakan sekumpulan huruf - huruf atau kalimat yang dipercayai sebagai penyembuh, kesaktian ataupun keselamatan) oleh atau alim ulama.

Menurut kepercayaan masyarakat sekitar daun Sawang ini berfungsi untuk menjaga masyarakat yang mengikuti Mandi Safar agar terjaga keselamatan dan terhindar dari segala gangguan baik dari binatang maupun makhluk halus, karena dalam Rajah Daun Sawang tersebut terdapat lafal "dua kalimat Syahadat". Kalimat tauhid tersebut dilafalkan selama mandi dan sesudah mandi, setelah melaksanakan Mandi Safar, Daun Sawang tersebut digantung didepan pintu rumah, yang mana orang tersebut akan selalu ingat akan lafal dan senantiasa mengucapkannya. (Ramadhan, wawancara : 2 Oktober 2018).

Setelah selesai Ritual Daun Rajah maka daun tersebut diberikan kepada seluruh masyarakat yang hadir. Setelah itu, masyarakat mulai menceburkan diri untuk mandi di Sungai Mentaya. Hal ini dilakukan agar masyarakat memiliki rasa saling menghargai antar sesama dan penjabat pemerintah, serta saling mengakrabkan dan menguatkan rasa persatuan pimpinan dan masyarakat. Dengan demikian kelestarian Sungai Mentaya menjadi kebanggaan masyarakat Sampit akan terjaga kebersihannya. Setelah selesai mandi, masyarakat berkumpul di pelabuhan Sampit untuk bersama - sama memohon doa keselamatan dan di pimpin oleh kiai setempat. Selanjutnya masyarakat sekitar memperebutkan aneka 
makanan yang dibentuk seperti gunungan yang terdiri dari 41 jenis kue tradisional seperti kue cucur, apem putih, apem merah, wajik, ketupat burung dan lain - lain. (Ramadhan, wawancara: 2 Oktober 2018).

Kegiatan tradisi Mandi Safar ini merupakan salah satu atraksi budaya yang bernuasa agama yang akan selalu dipromosikan guna menambah perbendaharaan objek wisata Kalimantan Tengah. Dengan banyaknya atraksi budaya diharapkan Kalimantan Tengah lebih dikenal luas terutama Sampit Kabupaten Kotawaringin Timur sehingga banyak wiasata mengunjungin wilayah ini. (Rois, wawancara: 29 September 2018).

Tradisi Mandi Safar ini sudah menjadi tradisi tahunan dan masuk dalam kalender pariwisata Kotawaringin Timur. Upacara ini biasanya dilaksanakan dan dipusatkan di Dermaga Habiring Hurung.

Namun dalam beberapa tahun ini Ritual Mandi Safar sudah dijadikan Event Pariwisata, karena Ritual Mandi Safar ini merupakan budaya masyarakat yang patut dilestarikan.

\section{Apsek - aspek Dakwah yang Menimbulkan Pro dan Kontra dalam Upacara Mandi Safar.}

Aspek-aspek yang terkandung di dalam mandi safar menyelaraskan dengan timbulnya prilaku yang mementingkan kepentingan bersama atau nilai solidaritas dalam tindakan masyarakat.

Tradisi mandi safar ini mengandung filosofi membersihkan diri dari halhal negatif, sehingga diharapkan bisa terhindar dari bala bencana dan kesialan seiring bersihnya badan yang mandi bercebur di Sungai Mentaya. Dilihat dari tata cara dan proses Mandi Safar terdapat beberapa aspek dakwah yang menimbulkan pro dan kontra antara lain:

Pertama, Aspek sosial mengandung kebersamaan atau kesetiakawan dalam tradisi mandi safar adalah fungsi dasar yang dijadikan pegangan. Tradisi Mandi Safar sebagai tradisi keagamaan dilakukan untuk memperkuat solidaritas kelompok masyarakat dari seluruh etnis mupun agama yang ada di wilayah Sampit dan sekitarnya.

Pengungkapan ini merupakan sikap dan tindakan secara bersama dalam tradisi, manusia tidak hanya menunjukan kebersamaan saja, tetapi justru memperkuat sikap - sikap itu. Tradisi keagamaan menanamkan sikap ke dalam kesadaran diri yang tinggi serta untuk memperkuat komunitas moral keagamaan. (O’dea, 1995: 7).

Dalam pandangan masyarakat tentang tradisi mandi safar yang dilakukan setiap tahunya, maka masyarakat memiliki pandangan yang berbeda-beda seperti yang diungkapkan oleh bapak Nicer Ramadhan selaku tokoh masyarakat yaitu sebagai berikut : 
Y. alkhusaeri, N. Machendrawaty, A. Aripudin

"Menurut pandangan saya, ada yang pro ada yang kontra itu masalah ritual mandi safar. Tapi di Alquran itu tidak melarang dan juga tida menganjurkan. Itu sebenarnya hanya doa syukuran dari pada orang tua mengenai rezeki yang didapat satu tahun itu. Karna disana kan mereka cuma mandi, niat mandi itukan seperti mandi hari-hari tapi niatnya membersihkan diri kemudian mengucapkan doa untuk terima kasih kepada tuhan telah memberikan rezeki yang banyak. (Ramadhan, wawancara: 2 Oktober 2018).

Dari hasil wawancara di atas dapat diambil argumen dalam tradisi Mandi Safar ada yang pro dan ada juga yang kontra tentang masalah tradisi mandi safar ini. Di dalam Alquran tidak melarang dan juga tidak menganjurkan untuk melakukan ritual tersebut. Menurut orang tua sekitar Mandi Safar ini hanya doa syukuran mengenai rezeki yang telah di dapat dalam setahun. Karena niat mereka melakukan mandi safar ini untuk membersihkan diri kemudian berdoa untuk mengucapkan terima kasih kepada tuhan telah memberikan rezeki yang banyak. Tradisi Mandi safar ini turun-temurun dari nenek moyang yang dilaksanakan setiap bulan safar. Tradisi Mandi Safar telah dijelaskan bukanlah suatu kewajiban yang harus dilakukan akan tetapi tradisi ini selalu dilaksanakan karena telah menjadi tradisi secara turun-temurun. (Rois, wawancara: 29 September 2018).

Menurut pandangan masyarakat sekitar sungai Mentaya bahwa Tradisi Mandi Safar sama halnya dengan acara syukuran. Masyarakat melakukannya dengan niat untuk membersihkan diri dari segala sesuatu yang buruk agar masyarakat terhindar dari musibah atau hal-hal yang tidak baik. Tradisi Mandi Safar yang telah menjadi tradisi turun-temurun ini, jika tidak di perkenalkan kepada para remaja maka tradisi ini akan bergeser ketika para remaja menganggap sebuah tradisi bukanlah hal yang sakral dan penting bagi mereka. (Riwut, wawancara: 3 Oktober 2018).

Selain itu juga tradisi Mandi Safar dilakukan untuk mempererat hubungan antara individu dengan kelompok agar dapat berinteraksi dan saling berkomunikasi sehingga masyarakat dapat menjalin hubungan baik dengan masyarakat lain ketika mereka sama - sama melakukan Tradisi Mandi Safar. Tradisi Mandi Safar dilaksanakan dan diperingati untuk menanamkan nilai-nilai kebudayaan pada diri setiap masyarakat dan remaja untuk tidak melupakan tradisi turun-temurun yang ttlah dibuat oleh para leluhur atau nenek moyang kita. Tradisi ini dibuat dengan tujuan yaitu sebagai rasa syukur masyarakat kepada Allah agar mereka terhindar dari segala bencana. (Ramadhan, wawancara: 2 Oktober 2018).

Kedua, aspek AqidahTradisi merupakan suatu bentuk perayaan yang berhubungan dengan beberapa keparcayaan dengan ditandai oleh sifat khusus, yang menimbulkan sifat khusus rasa hormat dalam arti merupakan suatu pengalaman yang suci. Pelangalamn ini mencakup sesuatu yang dibuat atau 
dipergunakan oleh manusia untuk menyatakan hubunganya dengan yang "Tertinggi" dan hubungan itu sesuatu yang sifatnya biasa atau umum, tetapi sesuatu yang bersifat istimewa, sehingga manusia membuat suatu cara yang pantas guna melaksanakan pertemuan itu, maka muncullah bentuk Tradisi agama seperti ibadat yang bertujuan untuk memohon ampun, atapun menyembah kepada Dzat Tertinggi. (Darori, 2000: 110).

Dalam Ketidakpastian dan ketidakberdayaan merupakan salah satu suatu perasaan yang pasti dialami oleh manusia. terutama pada saat ada sesuatu yang tidak bisa dinalar oleh pikiran manusia. Datangnya bencana, wabah penyakit atau musibah lainnya, dimana manusia tidak akan pernah dapat memperkirakan kapan datang, maka dalam keadaan separti ini manusia tidak bisa berbuat apa - apa selain berdoa dan memohon ampun kepada Allah SWT. Namun, berdoa sendiri - sendiri pun belum bisa mendatangkan suatu keyakinan dalam diri masing masing individu bahwa dirinya tidak akan tertimpa musibah dan bencana. Untuk itu, setiap orang memerlukan rasa untuk merasakan kegelisahan satu sama lain dan membutuhkan media untuk bisa menyatukan persepsi pada masyarakat.

Tradisi Mandi Safar merupakan salah satu media yang bisa mengumpulkan massa dalam jumlah banyak dalam rangka untuk berdoa dan berikhtiar bersama - sama. Dengan demikian ritual keagamaan dalam rangka pertemuan dan menjali hubungan individu dengan Yang Maha Tinggi, baik untuk memohon maupun memuja, terkadang dilakukan dengan berbagai macam cara yang dikaitkan dengan moment - moment tertentu. Misalnya: dalam ajaran Islam terdapat beberpa ritual seperti shalat istisqa (shalat untuk meminta hujan) yang mana ritual ini meminta untuk diturunkannya hujan dan shalat gerhana matahari atau bulan (shalat kusuf dan khusuf) shalat yang dilakukan pada saat terjadi gerhana matahari dan bulan dengan tujuan hanya untuk mendekatkan diri kepada Allah dalam rangka untuk mengungkapkan rasa keta'dziman dengan kekuasaan Allah. (Rois, wawancara: 29 September 2018).

Tradisi Mandi Safar ini sangat memungkinkan suatu individu saling berkomunikasi dengan yang lainnya. Tradisi Mandi Safar merupakan suatu pendekatan dimana pendekatan ini memandang cara pandang terhadap suatu masalah melalui perantara sesuatu sebagai alat pandangnya. (Ghazali, 1997: 23).

Menurut Bugin, ada dua pendekatan dalam keilmuan, yaitu pendekatan non ilmiah (unscientific) dan pendekatan ilmiah (scientific). Pendekatan non ilmiah merupakan suatu pendekatan dimana orang menjawab dorongan ingin tahu dan mencari kebenaran dengan cara atau metode yang tidak ilmiah. Sedangkan pendekatan ilmiah adalah suatu pendekatan diamana orang menjawab dorongan ingin tahu dan mencari kebenaran dengan cara atau metode ilmiah. (Bungin, 2006: 240-244).

Tradisi Mandi Safar hanyalah sebuah Tradisi yang dilakukan turun 
Y. alkhusaeri, N. Machendrawaty, A. Aripudin

temurun warisan dari nenek moyang suku melayu yang tumbuh dalam masyarakat sekitar dan memang harus di lesatrikan dan terus dilaksanakan agar tradisi ini tidak hilang oleh masa. Karena jika tidak dilaksanakan dan diikuti masyarakat sekitar yang masih kental akan tradisi budaya percaya bahwa musibah dan petaka akan menimpa dirinya dan keluarganya.

Jika dikaitkan dengan ajaran agama yang di anut yaitu agama Islam, sebenarnya sangat bertentangan karena menurut saya tradisi Mandi Safar yang merupakan salah satu kebudayaan yang ada di Kotawaringin timur (sampit) yang di anggap sebagai penolak bala dan mensucikan diri agar terhindar dari malapetaka sebenarnya tidak logis dan musyrik. Oleh karena itu, sebagian masyarakat Sampit masih ada yang menyakini bahwa tradisi Mandi Safar benar benar bisa mendatangkan keselamatan bagi dirinya atau menghindarkan dirinya dari bahya atupun musibah yang datang. Tapi tidak jarang yang lebih melihat rasional dalam melihat tradisi ini, di mana tradisi Mandi Safar hanyalah sekedar tradisi nenek moyang yang memiliki nilai budaya dan sosial kemasyarakatan yang tinggi. (Dani, wawancara: 3 Oktober 2018).

Ketiga, aspek Daun Sawang yang dirajah (ajimat), Merajah daun Sawang yaitu menulis tulisan arab, simbol - simbol maupun angka - angka tertentu yang hanya diketahui oleh pembuat. Fungsi dari Rajah ini sebagai ajimat dan sudah mengandung khodam ataupun kekuatan ghoib. Dalam Islam Rajah bisa disebut sebagai Jimat atau azimat. Azimat merupakan benda yang dijadikan sebagai penangkal dari suatu penyakit atapun musibah. Dalam kamus Mukhtar al-Shihah, disebutkan azimat adalah pelindung yang digantung pada manusia. (Al-Razy: 8).

Adapun dalam Islam sendiri bahwa azimat merupakan perbuatan Syirik, beberapa hadist menerangkan, antara lain:

Pertama, dari Abdullah, beliau berkata, aku mendengar Rasulullah SAW berasabda: Artinya : "Sesunggubnya ruqyah, arimat dan pelet adalah perbuatan syirik" (H.R Ahmad).

Kedua, dari 'Uqbah bin Amir bahwa beliau mendengar Rasulullah SAW bersabda: Artinya : "Barang siapa yang menggantungkan (bati) pada arimat, maka Allah tidak akan menyelesaikan urusannya. Barangsiapa yang menggantungkan dirinya pada kerang, maka Allah tidak akan memberikan kepadanya jaminan”. (H.R. Ahmad).

Ketiga, dalam riwayat lain disebutkan, Artinya : "Barangsiapa yang menggantungkan jimat, maka ia telah berbuat syirik”. (H.R. Ahmad).

Ketiga hadist diatas, menerangkan bahwa menggunakan azimat merupakan perbuatan tercela, bahkan termasuk perbuatan syirik yang mengacu pada hadist pertama dan kedua. Yang dimaksud dengan perbuatan syirik yaitu menyekutukan Allah atau memohon kepada selain Allah.

Walaupun beberapa hadist mengatakan bahwa menggunakan azimat dan ruqyah merupakan perbuatan syirik namun ada beberapa hadist juga yang memperbolehkan menggunakan azimat dan ruqyah selama tidak ada unsur syirik. 
Ruqyah dengan membaca ayat - ayat Alqur'an tertentu seperti yang diriwayatkan Abu Said Al-Khudri r.a berbunyi :

Artinya : "Babwa beberapa orang diantara sababat Rasulullab $S A W$, sedang berada dalam perjalanan melewati salah satu dari perkampungan Arab. Mereka berharap menjadi tamu penduduk kampung tersebut. Namun ternyata penduduk kampung itu tidak mau menerima mereka. Tetapi ada yang menanyakan: apakah di antara kalian ada yang dapat menjampi? Karena kepala kampung mereka terkena sengatan atau terluka. Seseorang dari para sahabat itu menjawab: Ya, ada. Orang itu lalu mendatangi kepada kampung dan menjampinya dengan surat Al - Fatibah. Ternyata kepala kampung itu sembuh dan diberikanlah kepadanya beberapa ekor kambing. Sababat itu menolak untuk menerimanya dan berkata: Aku akan menanyakan dabulu kepada Nabi SAW. Dia pun pulang menemui Nabi SAW dan menuturkan peristiwa tersebut. Dia berkata: Ya Rasulullab! Demi Allah, aku hanya menjampi dengan surat Al - Fatihah. Mendengar penuturan itu: Rasulullab SAW tersenyum dan bersabda: Tabukah engkau bahwa Al - Fatibab itu merupakan jampi? Kemudian Beliau melanjutkan: Ambillab imbalan dari mereka dan sisibkanlab bagianku bersama kalian. (H.R.Muslim).

\section{Pro dan Kontra Terhadap Tradisi Mandi Safar.}

Mandi Safar seperti tradisi tradisi lainnya yang berkembang dimasyarakat terkesan merupakan tradisi bernuansa agama, namun pada dasarnya tradisi tersebut bukanlah bagian dari agama. Sebab, Islam dalam Alqur'an dan Hadistnya tidak perah memerintahkan untuk melaksanakan Mandi Safar. Dalam tradisi Mandi Safar yang perlu dikedepankan adalah sapek "tradisi dan budaya" bukan aspek tradisi keagamaannya. Jika Mandi Safar dianggap sebagai tradisi keagamaan yang diawali dengan niat Mandi Safar, maka hal tersebut dikhawatirkan akan timbul pemahaman pada masyarakat bahwa Mandi Safar tersebut yang dapat menyembuhkan, menyelamatkan, dan menghindarkan orang dari bala bencana. Pemahaman seperti ini termasuk pemahaman syirik, sebab pada hakikatnya yang dapat menyembuhkan, menyelamatkan dan menghindarkan orang dari bala dan becana hanyalah Allah.

Bagi masyarakat suku banjar, mereka mempercayai bulan Safar dianggap sebagai bulan sial, bulan naas, bulan diturunkannya bala dan penyakit dan bulan yang harus diwaspadai keberadaannya. Hal - hal yang berbau magis ini memiliki kekuatan yang lebih dibandingkan pada bulan lainnya.

Karena sudah menjadi suatu hal kebiasaan bagi orang Suku Banjar, untuk menjauhkan dan menghindari sesuatu kesialan pada hari itu, orang Banjar melakukan atau melaksanakan kegiatan atau kebiasaan, yaitu : pertama, Sholat sunnah mutlak disertai doa tolak bala, kedua, Selamatan kampung, biasanya disertai dengan menulis rajah (ajimat) di atas piring kemudian dibilas dengan air, lalu dibagikan kepada masyarakat sekitar untuk diminum, ketiga, Mandi Safar 
Y. alkhusaeri, N. Machendrawaty, A. Aripudin

untuk membuang sial, penyakit, bala bencana, dan keempat, Tidak melakukan perjalanan jauh. (Ramadhan, wawancara: 2 Oktober 2018).

Kepercayaan masyarakat yang kental akan Adat dan budayanya menimbulkan sistem agama primitif seperti "animisme dan dinamisme". Menurut Durkheim sistem agama primitif terdapat dalam masyarakat yang sederhana, dan sistem agama tersebut dapat dijelaskan tanpa harus terlebuh dahulu mejelaskan elemen - elemen lain dari agama yang lebih tua darinya. Ia mengatakan bahwa agama primitif merupakan agama yang dapat membantu dalam menjelaskan hakikat religius manusia dibandingkan dengan bentuk agama lain. Adapun agama dalam arti objektif adalah segala sesuatu yang dipercayai, sedangkan agama dalam arti subjektif ialah cara bagaimana manusia berdiri di hadapan Tuhan dan bagaimana ia harus mentaati segala perintah dan larangan - Nya.

Secara teologis, suatu kegiatan keagamaan tidak mustahil akan bergeser dari kemurniannya bila bercampur dengan tradisi, karena terkesan sebagai kepercayaan bahkan keyakinan, namun maksud dan doktrinnya berubah - ubah. (Hamzah, 1998: 230).

Akulturasi budaya di Sampit menghasilkan corak beragama yang unik, meskipun sebagian ritual agamanya negatif. Budaya negatif yang dipertahankan oleh masyarakat Sampit sampai sekarang adalah upacara tolak bala, yaitu Mandi Safar dan Simah Laut.

Menurut Rois, pelesatrian dan pelaksanaan Mandi Safar bukan suatu pengkulturan budaya yang bermuara pada adanya suatu keyakinan bahwa apabila tidak melaksanakan atau mengikuti tradisi Mandi Safar ini maka orang tersebut akan mendapatkan becana atau pun musibah dan tidak selamat. Karena benana ataupun musibah yang datang kepada manusia itu sudah menjadi ketetapan Allah SWT sang pencipta alam semsta. Keselamatan dan kebahagaian manusia itu atas ketentuan Allah SWT di samping ikhtiar dan usaha dalam kehidupan yang benar, bukan tergantung dari tradisi Mandi Safar atau tradisi dan ritual - ritual lainnya yang tidak sesuai dengan tuntutan Allah SW'T dan Rasul - Nya. Disinilah yang menjadi suatu alasan perdebatan dan pertentangan bagi mereka yang tidak menikuti dan melaksanakan ataupun menentang tradisi Mandi Safar ini. (Rois, wawancara: 29 September 2018).

\section{PENUTUP}

Berdasarkan hasil analisis data mengenai Pergumulan Dakwah ditinjau dari pro dan kontra pada tradisi Mandi Safar dapat disimpulkan sebagai berikut:

Pertama, Tradisi Mandi Safar adalah proses untuk membersihkan jiwa dan membuang 330 bala yang turun. Tradisi Mandi Safar ini dilakukan untuk mengenang dan memperingati peristiwa mati Syahidina Husin bin Ali bin Abi Tholib yang memimpin tetntaranya berangkat dari Mekkah ke kota Kuffah. Harapan dari masyarakat pesisir Sungai Mentaya dari Tradisi Mandi Safar ini 
yakni dijauhkannya dari segala bala bahaya dan penyakit.

Mandi Safar seperti tradisi tradisi lainnya yang berkembang dimasyarakat terkesan merupakan tradisi bernuansa agama, namun pada dasarnya tradisi tersebut bukanlah bagian dari agama. Sebab, Islam dalam Alqur'an dan Hadistnya tidak perah memerintahkan untuk melaksanakan Mandi Safar. Dalam tradisi Mandi Safar yang perlu dikedepankan adalah sapek "tradisi dan budaya" bukan aspek tradisi keagamaannya. Jika Mandi Safar dianggap sebagai tradisi keagamaan yang diawali dengan niat Mandi Safar, maka hal tersebut dikhawatirkan akan timbul pemahaman pada masyarakat bahwa Mandi Safar tersebut yang menyembuhkan, menyelamatkan, dan menghindarkan orang dari bala bencana. Pemahaman seperti ini termasuk pemahaman syirik, sebab pada hakikatnya yang dapat menyembuhkan, menyelamatkan dan menghindarkan orang dari bala dan becana hanyalah Allah.

Kedua, Aspek-aspek yang terkandung di dalam mandi safar menyelaraskan dengan timbulnya prilaku yang mementingkan kepentingan bersama atau nilai solidaritas dalam tindakan masyarakat. Dilihat dari tata cara dan proses Mandi Safar terdapat beberapa aspek dakwah yang menimbulkan pro dan kontra antara lain:

Aspek sosial mengandung kebersamaan atau kesetiakawan dalam tradisi mandi safar adalah fungsi dasar yang dijadikan pegangan. Tradisi Mandi Safar sebagai tradisi dilakukan untuk memperkuat solidaritas kelompok masyarakat dari seluruh etnis mupun agama yang ada di wilayah Sampit dan sekitarnya.

Aspek Aqidah Jika dikaitkan dengan ajaran agama yang di anut yaitu agama Islam, sebenarnya sangat bertentangan karena tradisi Mandi Safar merupakan salah satu kebudayaan yang ada di Kotawaringin timur (Sampit) yang dianggap sebagai penolak bala dan mensucikan diri agar terhindar dari malapetaka sebenarnya tidak logis dan musyrik. Oleh karena itu, sebagian masyarakat Sampit masih ada yang menyakini bahwa tradisi Mandi Safar benar - benar bisa mendatangkan keselamatan bagi dirinya atau menghindarkan dirinya dari bahaya atupun musibah yang datang. Tapi tidak jarang yang lebih melihat rasional dalam melihat tradisi ini, di mana tradisi Mandi Safar hanyalah sekedar tradisi nenek moyang yang memiliki nilai budaya dan sosial kemasyarakatan yang tinggi.

\section{DAFTAR PUSTAKA}

\section{Buku}

Aripudin, Acep dan Sambas, (2007). Dakwah Damai (Pengantar Dakwah Antarbudaya), Bandung: Remaja Rodaskarya.

Cuzzort dan King. (1987). Kekuasaan, Birokrasi, Harta dan Agama di Mata Max Weber dan Emile Durkheim, Penyunting Mulyadi Guntur Wasesa, Yogyakarta: Hanindita. 
Y. alkhusaeri, N. Machendrawaty, A. Aripudin

Darori, Amin M, (2000). Islam dan Kebudayaan Jawa, Yogyakarta: Gama Media.

Dhofier, Zamakhsyari dan Wahid Abdurrahman, (1987). "Penafsiran Kembali Ajaran Agama: Dua Kasus dari Jombang”, dalam Prisma No. 03, Jakarta: LP3ES

Hamzah, Qusaeri M, (1998). Risalah Amaliah, Pemangkih.

Jandra, M, (2002). Islam dalam konteks Budaya da Tradisi Plural, dalam buku Agama dan Pluralitas Budaya lokal, Jina UMS Press.

Kahmad, Dadang. (2011). Sosiologi Agama. Bandung: Remaja Rosdakarya..

Kusumah, Hadi Hilman, (1993). Antropologi Agama, Bandung: Citra Aditya Bakti.

Mardalis, (1999). Metode Penelitian Suatu Pendekatan Proposal, Jakarta: Bumi Aksara..

Mattulada, (1997). Kebudayaan Kemanusiaan Dan Lingkungan Hidup, Hasanuddin University Press.

Moesliem, Abdurahman, (2003). Islam Sebagai Keritik Sosial, Jakarta: Penerbit Erlangga.

O’dea, F Thomas, (1995). Sosiologi Agama: Suatu Pengenalan Awal, Terj. Yasogama, Jakarta: PT Raja Grafindo Persada.

Paisun, (2010). Makalah "Dinamika Islam Kultural (Studi atas Dialektika Islam dan Budaya Lokal Madura)", ACIS Ke-10, Banjarmasin 1-4 November.

Soekanto, Soerjono. (2015). Sosiologi: Suatu Pengantar, Jakarta: Rajawali Press.

Soelaeman, Munandar M. (2011). Ilmu Sosial Dasar (Teori dan Konsep Ilmu Sosial), Bandung: PT Refika Aditama.

Schraf, Betty R. (1995). Kajian Sosiologi Agama, Yogyakarta: PT. Tiara Wacana Yogya.

Tajiri, Hajir. (2015). Etika dan Estetika Dakwah: Perspektif Teologis, Filosofis, dan Praktis. Bandung: Simbiosa Rekatama Media.

Wahid, Abdurrahman, (2001), Pergulatan Negara, Agama, dan Kebudayaan, Jakarta: Desantara.

Wirawan. I. B. (2012). Teori-Teori Sosial Dalam Tiga Paradigma. Jakarta; Prenadamedia Group.

\section{Jurnal}

Nurhidayah, Yayan. 2017. Kesenian Tari Topeng sebagai Media Dakwah. Dalam Ilmu Dakwah: Academy Journal 1 for Homiletic Studies 11 (1).

Aliyudin, Mukhlis. 2016. Dakwah Kultural dalam Upacara Adat Ngalaksa. Dalam Ilmu Dakwah: Academy Journal for Homiletic Studies 10 (2). 